\title{
Vibrational dynamics of 1,3-propanediol in liquid, polycrystalline and glassy states: a Raman spectroscopic study
}

\author{
Vlasta Mohaček-Grošev a,1* and Nikola Baran a \\ a Centre for Advanced Materials and Sensing Devices, Division of Materials Physics, \\ Ruđer Bošković Institute, Bijenička cesta 54, 10002 Zagreb, Croatia
}

\begin{abstract}
Vibrational transitions of 1,3-propanediol in liquid and crystal phases are assigned on the basis of Raman and infrared spectra of liquid and low temperature (295 K - 10K) Raman spectra which are presented here for the first time. In the crystal, there are four molecules per unit cell, each having a gGGg' conformation. The vibrations for the $P 2_{1} / n$ crystal phase having four molecules in the unit cell are obtained by an ab initio calculation using CRYSTALo9 program, and are in good agreement with the observed Raman bands. Observed bands in Raman spectrum of liquid are in proximity of those observed for crystal phase, and it is tempting to assign them as belonging mainly to gGGg' conformer. However, quantum chemical ab initio calculations provide basis to ascertain that tGG'g and tGGt are two conformers having lowest energy at the B3LYP/6-31++G(d,p) level of theory. Several bands that disappear from Raman spectrum of liquid on solidification $\left(384,872\right.$ and $\left.1040 \mathrm{~cm}^{-1}\right)$ could give an insight into the nature of conformers present in liquid. Since the closest calculated vibrations are $386 \mathrm{~cm}^{-1}$ for tGG'g and $1043 \mathrm{~cm}^{-1}$ for tGG't conformer, we conclude that all three conformers: $\mathrm{tGG}^{\prime} \mathrm{g}$, tGGt and $\mathrm{gGGg}$ ', are present in the liquid.
\end{abstract}

keywords: low temperature Raman spectroscopy, normal modes, CRYSTALo9, phonons, conformational analysis, renewable polymers

prepared for Spectrochimica Acta A: Molecular and Biomolecular Spectroscopy doi: $10.1016 /$ j.saa.2019.117567

\footnotetext{
${ }^{1}$ corresponding author, e-mail:mohacek@irb.hr
} 


\section{Introduction}

The rise of awareness concerning the amount of insoluble plastic ending in environment as well as limited amount of petroleum-based materials has stimulated research and production both of biodegradable and renewable polymers [1]. Until the last few years, less attention was paid to plastic products after their lifetime. This has changed, however, as new legislation procedures are being implemented in European Union and worldwide [2,3]. The market for 1,3-propanediol (PDO) amounts currently to over 100 million pounds per year and is growing rapidly [4]. The reason for this is that PDO can replace ethylene glycol and butylene glycol in the synthesis of polyesters and polyurethanes, in particular for polymethylene terephtalate $[4,5]$. In order to minimize greenhouse emission and consume less energy, the procedure for obtaining PDO has turned to microbial production based either on glycerol or on glucose $[4,6,7]$. Also, a research proposing PDO as a potential substitute of propylene glycol in refill liquid for electronic cigarettes has recently been published [8]. Vibrational spectroscopy is a well established experimental tool for process monitoring [9,10], often used in chemical plants and pharmaceutical companies [11]. It is therefore of interest to present vibrational spectroscopic characteristion of 1,3-propanediol.

Conformational states of 1,3-propanediol have been studied by Johansson in 1973 [12] and more thoroughly by Bultinck et al in 1995 [13]. Using ab initio methods Bultinck et al. optimized geometries of twenty three conformers and found that the most stable conformer had gauche O-C-C-C torsional angle. Semiempirical study of Friedemann and Jabs included monomers, dimers and monohydrates of PDO [14]. They found that intramolecular hydrogen bonds were preserved in dimers. Kinneging et al. performed an electron diffraction study on PDO which confirmed the existence of an intramolecular hydrogen bond [15]. The energy of the intramolecular hydrogen bond in 1,3-propandiol was estimated using quantum theory of atoms in molecules (QTAIM) by Mandado and coworkers in 2006 [16]. Takahashi studied the effect of hydrogen bonding on $\mathrm{OH}$ stretching overtone decay lifetime [17], while Muniz-Miranda et al. undertook Car-Parrinello molecular dynamics simulation of PDO/acetonitrile solutions and compared calculated vibrational density of states with the experimental infrared spectra in order to elucidate spectral components of intra- and intermolecular hydrogen bonding [18]. Thalladi, Boese and Weiss examined melting point alternation in alkanediols and reported the crystal structure of 1,3-propanediol to be $P_{2} / n$ with $\mathrm{Z}=4$ molecules per unit cell, $a=4.9396 \AA, b=7.9436 \AA, c=10.6007 \AA, \beta=90.097^{\circ}$ [19]. Emel'yanenko and Verevkin authored benchmark thermodynamic study of 1,3propanediol which used vapour pressure temperature dependence measurements for the derivation of molar enthalpy of vaporisation [20]. They also calculated thermal populations of each PDO conformer using G3MP2 under Gaussiano9, and predicted that $40 \%$ of free PDO molecules have tGG'g conformation, $20 \%$ gGG'g conformation, and $18 \%$ tGG't conformation (in Bultinck notation).

Vibrational studies of 1,3-propanediol are scarce. Both Busfield et al. [21] and Shagidullin with coworkers [22] performed an infrared study of dilute solutions of PDO in carbon tetrachloride in order to study intramolecular hydrogen bonding. Shagidullin et al. presented also infrared spectra of the PDO in gas phase and discussed temperature dependence of some Raman bands, but did not give a complete list of 
bands with proper assignment [22]. Both groups concentrated on the $\mathrm{O}-\mathrm{H}$ stretching spectral region.

In this work Raman and infrared specta of liquid are reported and the observed bands interpreted on the basis of normal mode calculation for a set of five conformers. Several Raman bands disappearing on solidification are singled out and discussed. Also, temperature dependent Raman spectra starting form $295 \mathrm{~K}$ to $10 \mathrm{~K}$ are presented for the first time. In the crystal, 1,3-propanediol molecules take up the $\mathrm{gGGg}^{\prime}$ conformation. Low temperature Raman phonons observed for polycrystalline PDO are assigned on the basis of an ab initio optimization of the crystal structure and frequencies calculation done by CRYSTALo9 program. Furthermore a glassy state was observed on freezing of the liquid to $160 \mathrm{~K}$ and lower temperatures.

\section{Experimental}

1,3-Propanediol was purchased from Aldrich as $98 \%$ pure liquid. On opening the bottle, approx. $100 \mu \mathrm{l}$ of the liquid was transferred by a syringe into a capillary connected to vacuum line. Using a freeze-pump-thaw procedure, repeated degassing of $\mathrm{N}_{2}$ and $\mathrm{O}_{2}$ from the sample was done. Once sealed, the capillary was mounted onto the cold finger of a closed cycle helium optical cryostat CCS 350 from Janis Research, connected to the Lake Shore 331 temperature controller.

Raman spectra were recorded with T64000 Horiba-JobinYvon spectrometer in the triple subtractive configuration, using both single window and multiwindow options. For excitation, a semiconductor laser DPSS $532 \mathrm{~nm}$ from Changchun New industries Optoelectronics Tech. was used. Liquid nitrogen cooled CCD detector for VIS region with 1024 x 256 pixels served as a detector. Spectral resolution was $0.6 \mathrm{~cm}^{-1}$ per pixel. Average acquisition time was 20 seconds and four scans were averaged for the final result.

Infrared spectrum was recorded using a Perkin Elmer liquid cell with two circular $\mathrm{KBr}$ windows with a $20 \mu \mathrm{m}$ spacer between. The empty cell was used for background recording with a SPECTRUM GX Perkin Elmer Fourier transform spectrometer. For sample spectrum recording $1 \mu$ drop of propanediol was put on one window, covered with spacer and the other window and tightly pressed with screws. Fifty scans with 4 $\mathrm{cm}^{-1}$ resolution were chosen set of conditions.

\section{Computational details}

Normal mode calculations for tGG'g, tGGt, gGGg', gGG'g and tTTt conformers were performed with the Gaussiano9 program [23]. The geometry of the propanediol was optimized using B3LYP functional with 6-31++G(d,p) basis set, without imposing symmetry restrictions upon geometry. For potential energy distribution calculation BALGA program was used [24,25]. Definition of internal coordinates is given in Supplementary table S1, while local symmetry coordinates are listed in Supplementary table S2. Finally, a detailed potential energy distribution for tGG'g and tGGt conformers is presented in Table 1, while for tTTt conformer it is given in Supplementary table S3 and for gGGg' in the Supplementary table S4. 
For the $P 21 / n$ crystal structure partial optimization of atomic positions with fixed cell parameters was performed first using density functional theory as implemented in CRYSTALo9 program [26]. The correlation functional of Lee, Yang and Parr [27] with generalized gradient approximation and the exchange functional of Becke [28] popularly kown as B3LYP functional were used.

When the SHRINK keyword defining the grid of k points was set to 4, 4 and 2, the total energy of the crystal was ET $=-1077,7779$ Hartree without dispersion correction and $-1077,9252$ Hartree when dispersion correction as described by Grimme [29] was taken into account. The convergence criteria for energy during geometry optimization was set to $10^{-7}$ Hartree, whereas for calculation of vibrations it was $10^{-10}$ Hartree. Extra large grid was used. Basis sets for carbon, hydrogen and oxygen of the 6-31G** type were transferred from the study of urea by Gatti et al [30]. This basis set has been found adequate for calculations on molecular crystals by Barone [31]. The calculations were run on HP Z640 workstation using eight processors.

\section{Results and Discussion}

\subsection{Conformational analysis of liquid propanediol}

Previous conformational studies of PDO were conducted by Bultinck et al. [13] and Emel'yanenko and Verevkin [20], while Mandado et al. [16] inspected just three conformers displaying intramolecular hydrogen bonding. The capital letters $\mathrm{G}$ and $\mathrm{G}^{\prime}$ refer to positive or negative torsional angle of gauche conformation with respect to the torsion around one or the other $\mathrm{C}-\mathrm{C}$ bond. Small t or g letters refer to trans or gauche conformation for the rotation around $\mathrm{C}-\mathrm{O}$ bonds. Both Bultinck et al. and Emel'yanenko and Verevkin found there are three conformers within the $2 \mathrm{~kJ} / \mathrm{mole}$ energy difference, and both groups concluded that the tGG'g is the most stable conformation of PDO. The second conformer in the order of rising energies is found by both groups to be $\mathrm{gGG} g$, but in the third conformer the predictions of two groups differ. Bultinck et al. calculated the tGGg' conformation to be $6.96 \mathrm{~kJ} / \mathrm{mol}$ above the energy of the tGG'g, while Emel'yanenko and Verevkin reported that the third conformation in the rising order is tGG't and has only $2.03 \mathrm{~kJ} / \mathrm{mol}$ higher energy than the tGG'g. We repeated the calculations for tGG'g and gGG'g coformers, and included also gGGg' conformation that is found in crystal state as well as tGGt and tTTt. Using B3LYP/6-31++G(d,p) level of theory, we found that tGG' $g$ is the most stable conformer, followed by tGGt $(6.82 \mathrm{~kJ} / \mathrm{mol}$ higher energy), gGGg' (8.36 kJ/mol higher), gGG'g $(10.77 \mathrm{~kJ} / \mathrm{mol}$ higher) and tTTt (13.39 kJ/mol higher than the energy of tGG'g). In the units of Hartree, the energies of the three most stable conformations are

-269.5949925 Ha (tGG'g), -269.5923931 Ha (tGGt), and -269.591806414 Ha (gGGg') (see Fig 1). Since we obtained all positive frequencies of normal modes for all five conformers, we find them stable. On the contrary, Mandado et al. [16] stated that tGG'g conformer was not a stable one (they used B3LYP/6-311++G(2d,2p) procedure).

For the three conformers having lowest energy one can compare thirty three positive frequencies with the observed Raman and infrared bands for liquid and crystalline 
PDO (Figs 2 and 3, Supplementary figs S2 - S5, Tables 1 and 2, Supplementary table S4). The tGGg' and gGGg' conformers have no symmetry elements, and the tGGt has one $\mathrm{C}_{2}$ axes. Hence, in each case all thirty three modes are observable both in Raman and infrared spectra of liquid. In Table 1 the calculated unscaled vibrations belonging to the tGG'g conformer $\left(\tau_{1}=-175.8^{\circ}, \tau_{2}=59.6^{\circ}, \tau_{3}=-72.4^{\circ}, \tau_{4}=46.8^{\circ}\right)$ and tGGt $\left(\tau_{1}=\right.$ $-172.2^{\circ}, \tau_{2}=65.4^{\circ}, \tau_{3}=65.4^{\circ}, \tau_{4}=-172.4^{\circ}$ ) are compared with Raman and infrared bands of liquid and Raman bands observed for polycrystalline PDO. Calculated normal modes of the gGGg' conformer are given in Supplementary table $\mathrm{S}_{4}$. Its torsional angles obtained upon geometry optimization are $\tau_{1}=66.9^{\circ}, \tau_{2}=50.9^{\circ}, \tau_{3}=54.9^{\circ}, \tau_{4}=-78.8^{\circ}$.

Many observed bands in Raman spectra of liquid and crystal have very close wavenumbers, and it is tempting to assign them belonging mainly to gGGg' conformer. From skeletal deformation modes which are usually observed below $600 \mathrm{~cm}^{-1}$ one can make an attempt to deduce which conformer is present in liquid. In the infrared spectrum of liquid a band at $528 \mathrm{~cm}^{-1}$ is found, whereas in Raman spectrum of liquid one observes bands at 529, 412, 384 and $278 \mathrm{~cm}^{-1}$. The band at $384 \mathrm{~cm}^{-1}$ observed in Raman spectrum of liquid disappears on freezing (Fig 3), just as the bands observed at $872 \mathrm{~cm}^{-1}$ and $1040 \mathrm{~cm}^{-1}$. The $412 \mathrm{~cm}^{-1}$ and $529 \mathrm{~cm}^{-1}$ Raman bands observed in liquid have their counterparts in $445 \mathrm{~cm}^{-1}$ and $535 \mathrm{~cm}^{-1}$ bands in Raman spectrum of solid at $170 \mathrm{~K}$ (Fig 3).

Before discussing the origin of the forementioned bands, let us remind ourselves of the lowest frequency modes of propane. The $\mathrm{C}-\mathrm{C}-\mathrm{C}$ bending band was attributed to the $369 \mathrm{~cm}^{-1}$ band, and the methyl torsions to 208 and $223 \mathrm{~cm}^{-1}$ bands [32]. Between 400 and $740 \mathrm{~cm}^{-1}$ no fundamental was assigned, but a methylene rocking band was observed at $748 \mathrm{~cm}^{-1}$. In 1,3-propanediol seven low frequency modes below $700 \mathrm{~cm}^{-1}$ are expected: a C-C-C bending, two $-\mathrm{CH}_{2} \mathrm{OH}$ torsional vibrations, two $-\mathrm{OH}$ torsional and two $\mathrm{C}-\mathrm{C}-\mathrm{O}$ bending vibrations. The actual values of normal modes frequencies that are calculated correspond to the gas phase, whereas the positions of measured bands given in Table 1 refer to condensed phases. Therefore, large discrepancies between calculated and observed wavenumbers are expected for modes involving - $\mathrm{OH}$ groups. The C-C-C skeletal bending mode is predicted at $330 \mathrm{~cm}^{-1}$ for tGG'g conformer, at 239 $\mathrm{cm}^{-1}$ (mixed) for gGGg' conformer and at $528 \mathrm{~cm}^{-1}$ for tGGt conformer. Two O-C-C bending modes are calculated to be 386 and $192 \mathrm{~cm}^{-1}$ for tGG'g conformer, at 415 and $265 \mathrm{~cm}^{-1}$ for tGGt conformer, and at 572 and 405 for gGGg' conformer.

On freezing, one observes at $10 \mathrm{~K}$ Raman bands at 535, 445, 306, 300, and $278 \mathrm{~cm}^{-1}$, the bands at 306 and 300 being interpreted as crystal splitting of the one internal mode. The disappearance of the $384 \mathrm{~cm}^{-1}$ Raman band from liquid is interesting in view of the existing conformation of PDO molecules in crystal: they all have $\mathrm{gGGg}^{\prime}$ conformation: $\tau_{1}=67.6^{\circ}, \tau_{2}=61.5^{\circ}, \tau_{3}=69.4^{\circ}, \tau_{4}=-82.6^{\circ}$ (Fig 4). Therefore the 384 $\mathrm{cm}^{-1}$ band is attributed to another conformer in liquid, possibly tGG'g. The other two strong bands in Raman spectrum of liquid which disappear on freezing are at 1040 and $872 \mathrm{~cm}^{-1}$. Judging on the basis of calculated values for tGGt conformer that are in proximity - 853 and $1043 \mathrm{~cm}^{-1}$ - as well as the bands calculated for tGG'g conformer at 905 and $1076 \mathrm{~cm}^{-1}$, one could assign the $1040 \mathrm{~cm}^{-1}$ band to the tGGt conformer (see Fig 5 for comparison of calculated and observed spectral intensities for different 
conformers). In Supporting Material all Gaussiano9 output files for the tGG'g, tGGt and gGGg' are given, including the tTTt conformer. The tTTt conformer was included because of the possibility that end-to-end hydrogen bonding in liquid might prefer all trans conformation of PDO molecule, but some bands could not be assigned (printed in italic in the Supplementary table $\mathrm{S}_{3}$ ).

\subsection{Raman spectra of polycrystalline propanediol}

Propanediol is a transparent, slightly oily liquid, which exhibits significant supercooling and solidifies in polycrystalline form at $170 \mathrm{~K}$ when slowly cooled (the melting point reported is $246 \mathrm{~K}$ [34]). On rapid cooling, it forms a glassy state, whose Raman spectrum is at the top in Fig 2. The lowest band observed in glassy state at 10 $\mathrm{K}$ is found at $51 \mathrm{~cm}^{-1}$ (Supplementary Fig $\mathrm{S}_{5}$ ), whereas the Bose peak characteristic for disordered systems was measured in 1,3-propanediol liquid at $24 \mathrm{~cm}^{-1}$ [35]. The $51 \mathrm{~cm}^{-}$ ${ }^{1}$ band was attributed to the torsional modes of methoxy groups. The space group of the PDO crystal is $P 2_{1} / n$ with four molecules per unit cell [19], see Fig 4 . No atom is situated on any of the symmetry elements in the cell and the expected number of vibrations (phonons) is:

$$
\Gamma_{T O T}=39 A_{g} \oplus 39 B_{g} \oplus 38 A_{u} \oplus 37 B_{u} .
$$

Phonons of the $A_{g}$ and $B_{g}$ symmetry are Raman active, while those of $A_{u}$ and $B_{u}$ symmetry are infrared active. Below $250 \mathrm{~cm}^{-1}$ one expects collective librational and translational modes of the symmetry:

$$
\Gamma_{\text {ext }}=6 A_{g} \oplus 6 B_{g} \oplus 5 A_{u} \oplus 4 B_{u} .
$$

Within rigid molecule approximation, librations are Raman active, since their symmetry is of the gerade type, while translational modes are infrared active because they belong to $A_{u}$ and $B_{u}$ irreducible representations. Therefore in low frequency Raman spectrum one expects at least 12 modes, but seven are observed (Supplementary Fig S5, Table 2). The majority of bands occur at slightly shifted wavenumbers with respect to those observed in liquid, the exception being of course bands corresponding to modes involved in hydrogen bonding. For every internal mode that is observable in liquid spectrum, there are four corresponding phonons in the crystal, of $A_{g}, B_{g}, A_{u}$ and $B_{u}$ symmetry. Therefore for every band observed in Raman spectrum of liquid, one expects two new bands in the Raman spectrum of crystal. Sometimes not all vibrational modes could be resolved in liquid, such as in the case of C-H stretching bands which we expect six, but observe three: at 2887, 2913 and 2958 $\mathrm{cm}^{-1}$. At $10 \mathrm{~K}$ one observes seven out of eight expected bands: 2881, 2889, 2908, 2917, 2943, 2954 and $2978 \mathrm{~cm}^{-1}$. In Supporting Material the list of calculated phonons by CRYSTALO9 program is presented. In Table 2. a partial list of calculated phonons below $55 \mathrm{O} \mathrm{cm}^{-1}$ is given, where good agreement between observed and calculated bands positions is found. 
There are two types of intermolecular $\mathrm{O}-\mathrm{H} \cdots \mathrm{O}$ hydrogen bonds in the PDO crystal, corresponding to $\mathrm{O} \cdots \mathrm{O}$ distances of $2.698 \AA$ and $2.722 \AA$ (see Fig 4). According to Novak [34] these would be weak hydrogen bonds with $v(\mathrm{OH})$ above $3200 \mathrm{~cm}^{-1}$. Indeed, one finds three out of four expected broad bands at $10 \mathrm{~K}$ : at 3265,3250 and $3159 \mathrm{~cm}^{-1}$. The $\delta(\mathrm{C}-\mathrm{O}-\mathrm{H})$ bending modes are mixed with other modes, in particular with $\delta(\mathrm{H}-\mathrm{C}-$ $\mathrm{C})$ and $\delta(\mathrm{H}-\mathrm{C}-\mathrm{O})$ angle deformation vibrations, and significantly contribute to 1191 and $1222 \mathrm{~cm}^{-1}$ modes attributed to the tGG'g conformer (Table 1). The potential energy distribution shows that $1052 \mathrm{~cm}^{-1}$ mode of the $\mathrm{gGG}^{\prime} \mathrm{g}$ conformer has a significant contribution of the $\delta(\mathrm{C}-\mathrm{O}-\mathrm{H})$ bending vibration (Supplementary material). The torsion of hydroxyl groups is assigned to a very broad band in the infrared spectrum observed at $666 \mathrm{~cm}^{-1}$ (Supplementary figure S2), and it could correspond to a weak $695 \mathrm{~cm}^{-1}$ band observed in Raman spectrum of polycrystalline sample at $10 \mathrm{~K}$ (Fig 3).

\section{Conclusion}

The assignment of normal modes of 1,3-propanediol has been given on the basis of Raman and infrared bands observed in spectra of liquid. Good agreement has been achieved in assigning the majority of observed bands as belonging to tGG'g and tGGt conformers. The band observed at 384 in Raman spectrum of liquid is assigned to the OCC bending of the tGG'g conformer. It disappears from Raman spectrum on solidification, just as the bands at 872 and $1040 \mathrm{~cm}^{-1}$. The $1040 \mathrm{~cm}^{-1}$ band could be assigned to the tGGt conformer since a 1043 mode is predicted for its $\mathrm{C}-\mathrm{C}$ bending motion. Raman spectra of solid 1,3-propanediol were recorded from $295 \mathrm{~K}$ to $10 \mathrm{~K}$. No indications of a phase transition have been found - the number of external phonons remains the same throughout the temperature interval studied (170 K - 10 K). When rapidly cooled, propanediol solidifies in a glassy state.

\section{Acknowledgement}

This work was partially supported by Centre of Excellence for Advanced Materials and Sensors, a project co-financed by the Croatian government and the European Union through the European regional development fund - The Competitivness and Cohesion Operational Programme (KK.o1.1.1.01). Calculations using Gaussiano9 were performed at University of Zagreb Computing Centre SRCE.

\section{References}

1. http://www.weforum.org/agenda/2018/08/the-world-of-plastics-in-numbers/

2.

https://www.plasticseurope.org/application/files/5715/1717/4180/Plastics the fact s 2017 FINAL for website one page.pdf

3. „A European Strategy for Plastics in a Circular Economy“, Commission Staff Working Document, http://ec.europe.eu/environment/circular-economy/indexen.htm.

4. H. Liu, Y. Xu, Z. Zheng, D. Liu, Biotechnology J. 5 (2010) 1137 - 1148. 
5. T. Debuissy, P. Sangwan, E. Pollet, L. Avérous, Polymer 122 (2017) 105 -116.

6. X. Yang, D. S. Kim, H. S. Choi, C. K. Kim, L. P. Thapa, C. Park, S. W. Kim, Chem. Eng. J. 314 (2017) 660 -669.

7. E. Tabah, A. Varvak, I. Neel Pulidindi, E. Foran, E. Banin, A. Gedanken, Green Chemistry 18 (2016) 4657.

8. P. Bertrand, B. Bonnarme, A. Piccirilli, P. Ayrault, L. Lemée, G. Frapper, J. Pourchez, Scientific Reports 8 (2018) 10702.

9. T. DeBeer, A. Burggraeve, M. Fonteyne, J. P. Remon, C. Vervaet, Int. J. Pharmaceutics 417(1-2) (2011) 32-47.

\section{0. http://www.recendt.at/en/IR.html}

11. K. Buckley, A. G. Ryder, Applied Spectroscopy 71(6) (2017) 1085 - 1116.

12. A. Johansson, P. Kollman, S. Rothenberg, Chem. Phys. Lett. 18 (1973) $276-279$.

13. P. Bultinck, A. Goemine, D. Van de Vondel, J. Mol. Struct. (Theochem) 357 (1995) $19-32$.

14. R. Friedemann, A. Jabs, J. Mol. Struct. (Theochem) 283 (1993) 191 - 197.

15. A. J. Kinneging, V. Mom, F. C. Mijlhoff, G. H. Renes, 82 (1982) 271 - 275.

16. M. Mandado, R. A. Mosquera, C. Van Alsenoy, Tetrahedron 62 (2006) 4243 - 4252.

17. K. Takahashi, Physical Chemistry Chemical Physics 12 (2010) 13950 -13961.

18. F. Muniz-Miranda, M. Pagliai, G. Cardini, R. Righini, J. Chem. Phys. 137 (2012) 244501.

19. V. R. Thalladi, R. Boese, H.-C. Weiss, Angew. Chem. Int. Ed. 39 (2000) 918 - 922.

20. V. N. Emel'yanenko, S. P. Verevkin, J. Chem. Thermodynamics 85 (2015) 111 - 119.

21. W. K. Busfield, M. P. Ennis, I. J. McEwen, Spectrochim. Acta A 29 (1973) 1259 1264 .

22. Rif. R. Shagidulin, A. V. Chernova, A. Kh. Plyamovtyi, R. R. Shagidullin, Bull. Acad. Sci. USSR 40 (10) (1991) 1993 - 1999.

23. Gaussian 09, Revision A.02, M. J. Frisch, G. W. Trucks, H. B. Schlegel, G. E. Scuseria, M. A. Robb, J. R. Cheeseman, G. Scalmani, V. Barone, G. A. Petersson, H. Nakatsuji, X. Li, M. Caricato, A. Marenich, J. Bloino, B. G. Janesko, R. Gomperts, B. Mennucci, H. P. Hratchian, J. V. Ortiz, A. F. Izmaylov, J. L. Sonnenberg, D. WilliamsYoung, F. Ding, F. Lipparini, F. Egidi, J. Goings, B. Peng, A. Petrone, T. Henderson, D. Ranasinghe, V. G. Zakrzewski, J. Gao, N. Rega, G. Zheng, W. Liang, M. Hada, M. Ehara, K. Toyota, R. Fukuda, J. Hasegawa, M. Ishida, T. Nakajima, Y. Honda, O. Kitao, H. Nakai, T. Vreven, K. Throssell, J. A. Montgomery, Jr., J. E. Peralta, F. Ogliaro, M. Bearpark, J. J. Heyd, E. Brothers, K. N. Kudin, V. N. Staroverov, T. Keith, R. Kobayashi, J. Normand, K. Raghavachari, A. Rendell, J. C. Burant, S. S. Iyengar, J. Tomasi, M. Cossi, J. M. Millam, M. Klene, C. Adamo, R. Cammi, J. W. Ochterski, R. L. Martin, K. 
Morokuma, O. Farkas, J. B. Foresman, and D. J. Fox, Gaussian, Inc., Wallingford CT, 2016.

24. G. Keresztury, G. Jalsovszky, J. Mol. Struct. 10 (1971) 304-305.

25. H. Rostkowski, L. Lapinski, M. Nowak, Vib. Spectrosc. 49 (2009) 43-51.

26. R. Dovesi, R. Orlando, B. Civalleri, C. Roetti,V. R. Saunders, C. M. Zicovich-Wilson, CRYSTAL: a Computational Tool for the Ab Initio Study of the Electronic Properties of Crystals Z. Kristallogr. 220 (2005) 571-573.

27. C. Lee, W. Yang, R. G. Parr, Phys. Rev. B 37 (1988) 785-789.

28. A. D. Becke, Phys. Rev. A 38 (1988) 3098-3100.

29. S. Grimme, J. Comput. Chem. 27 (2006) 1787-1799.

30. C. Gatti, V. R. Saunders, C. Roetti, J. Chem. Phys. 101 (1994) 10686-10696.

31. V. Barone, J. Chem. Phys. 122 (2005) 014108.

32. J. N. Gayles Jr., W. T. King, J. H. Schachtschneider, Spectrochim. Acta A 23 (1967) $703-715$.

33 .

https://web.archive.org/web/20041227154049/http://www.shellchemicals.com/che micals/pdf/pdo/brochure.pdf? section=our products

34. A. Novak, „Structure and Bonding“, vol. 18, Springer Verlag 1974. p. 177 - 216.

35. O. Yamamura, K. Harabe, T. Matsuo, K. Takeda, I. Tsukushi, T. Kanaya, J. Phys.: Condens. Matter 12 (2000) 5143-5154. 
Table 1. Unscaled normal modes of tGG'g and tGGt 1,3-propanediol are compared with the observed bands. Potential energy distribution (PED) among symmetrized coordinates is calculated by BALGA ${ }^{\dagger}$ program. Contributions greater than $10 \%$ are given. v-very, s-strong, m-medium, w-weak, sh-shoulder, brbroad

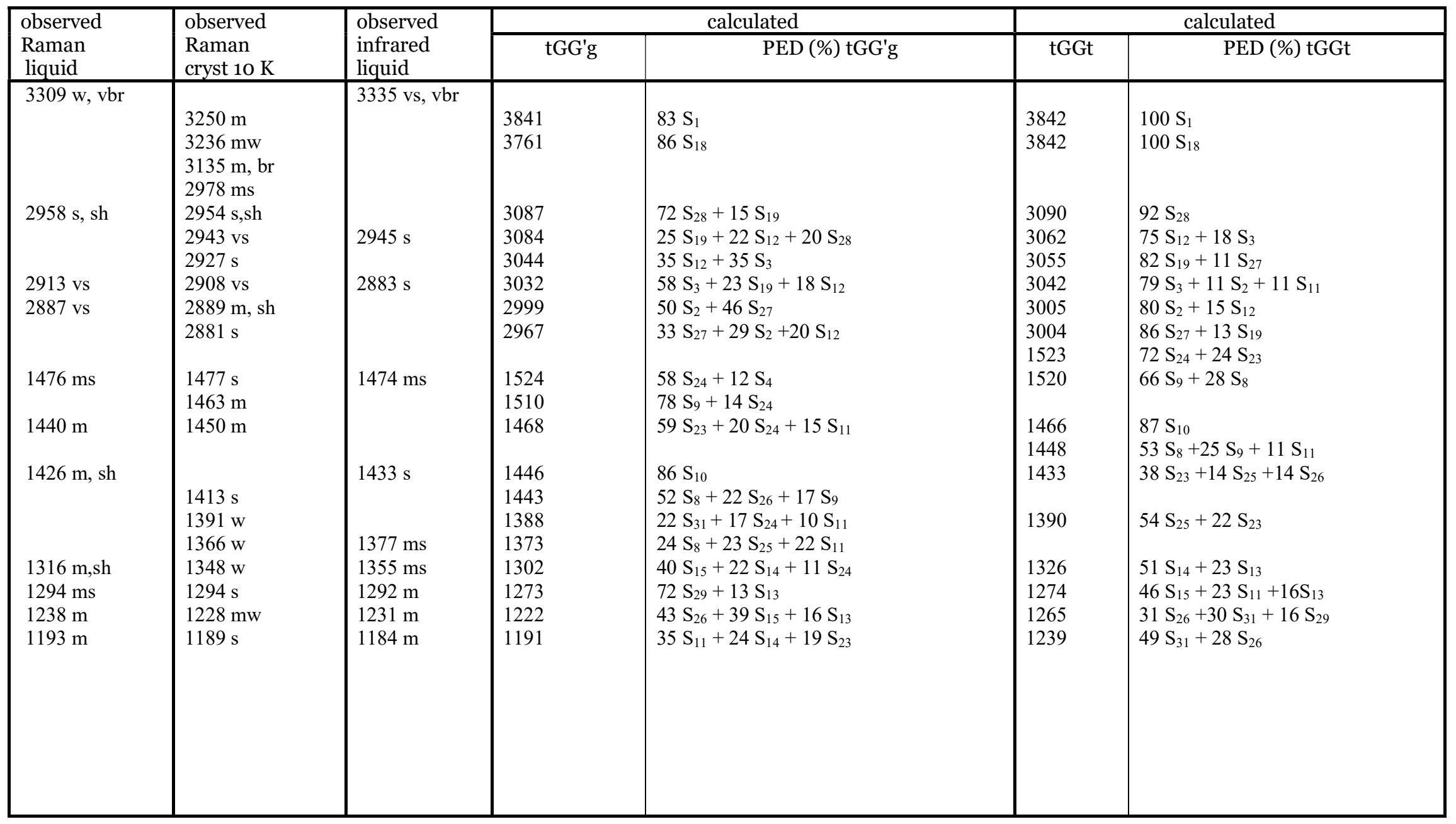




\begin{tabular}{|c|c|c|c|c|c|c|}
\hline $\begin{array}{l}1097 \mathrm{~m}, \mathrm{sh} \\
1062 \mathrm{~ms} \\
1040 \mathrm{~m}, \mathrm{sh} \\
986 \mathrm{~m} \\
941 \mathrm{~m} \\
920 \mathrm{~m} \\
872 \mathrm{~s} \\
850 \mathrm{~s} \\
815 \mathrm{w} \\
782 \mathrm{w} \\
\\
529 \mathrm{mw} \\
412 \mathrm{w} \\
384 \mathrm{w} \\
278 \mathrm{vw}\end{array}$ & $\begin{array}{l}1086 \mathrm{~m} \\
1062 \mathrm{~m} \\
\\
992 \mathrm{~s} \\
947 \mathrm{~m} \\
935 \mathrm{~m} \\
\\
853 \mathrm{vs} \\
808 \mathrm{w} \\
774 \mathrm{~m} \\
714 \mathrm{w} \\
\\
535 \mathrm{~m} \\
445 \mathrm{w} \\
\\
306, \mathrm{w} 300 \mathrm{sh} \\
278 \mathrm{w} \\
220 \mathrm{mw} \\
187 \mathrm{vw} \\
124 \mathrm{w} \\
102 \mathrm{w} \\
80 \mathrm{w}, \mathrm{sh} \\
75 \mathrm{~m} \\
47 \mathrm{w}\end{array}$ & $\begin{array}{l}1063 \mathrm{vs} \\
1038 \mathrm{~s} \\
986 \mathrm{~s} \\
940 \mathrm{~m} \\
921 \mathrm{~m} \\
869 \mathrm{w} \\
847 \mathrm{w} \\
782 \mathrm{~m} \\
666 \mathrm{~m} \text {, vbr } \\
528 \mathrm{~m}\end{array}$ & $\begin{array}{l}1132 \\
1088 \\
1076 \\
\\
954 \\
912 \\
905 \\
\\
814 \\
192 \\
\\
\\
531 \\
504 \\
\\
386 \\
330 \\
280 \\
\\
\\
\end{array}$ & $\begin{array}{l}54 \mathrm{~S}_{31}+16 \mathrm{~S}_{30} \\
42 \mathrm{~S}_{4}+14 \mathrm{~S}_{20}+11 \mathrm{~S}_{21} \\
47 \mathrm{~S}_{21}+13 \mathrm{~S}_{25} \\
\\
47 \mathrm{~S}_{13}+19 \mathrm{~S}_{15} \\
32 \mathrm{~S}_{20}+25 \mathrm{~S}_{30} \\
69 \mathrm{~S}_{5}+10 \mathrm{~S}_{30} \\
36 \mathrm{~S}_{20}+23 \mathrm{~S}_{7}+15 \mathrm{~S}_{4}+15 \mathrm{~S}_{31} \\
71 \mathrm{~S}_{32}+13 \mathrm{~S}_{6} \\
48 \mathrm{~S}_{17}+18 \mathrm{~S}_{33} \\
68 \mathrm{~S}_{7}+22 \mathrm{~S}_{30} \\
93 \mathrm{~S}_{22} \\
46 \mathrm{~S}_{6}+15 \mathrm{~S}_{33}+13 \mathrm{~S}_{17} \\
30 \mathrm{~S}_{33}+23 \mathrm{~S}_{17}+14 \mathrm{~S}_{6} \\
100 \mathrm{~S}_{16}\end{array}$ & $\begin{array}{c}1168 \\
1123 \\
1092 \\
\\
1043 \\
998 \\
965 \\
\\
853 \\
793 \\
167 \\
\\
529 \\
417 \\
\\
\\
266 \\
239 \\
238 \\
87\end{array}$ & $\begin{array}{l}50 \mathrm{~S}_{11}+19 \mathrm{~S}_{15}+16 \mathrm{~S}_{14} \\
27 \mathrm{~S}_{13}+21 \mathrm{~S}_{4}+20 \mathrm{~S}_{15} \\
54 \mathrm{~S}_{20}+17 \mathrm{~S}_{21}+12 \mathrm{~S}_{30} \\
42 \mathrm{~S}_{21}+27 \mathrm{~S}_{26}+15 \mathrm{~S}_{30} \\
67 \mathrm{~S}_{4}+15 \mathrm{~S}_{13}+12 \mathrm{~S}_{14} \\
35 \mathrm{~S}_{20}+34 \mathrm{~S}_{29}+13 \mathrm{~S}_{25} \\
\\
78 \mathrm{~S}_{5} \\
42 \mathrm{~S}_{30}+26 \mathrm{~S}_{29}+13 \mathrm{~S}_{20} \\
80 \mathrm{~S}_{32}+15 \mathrm{~S}_{33} \\
\\
47 \mathrm{~S}_{7}+28 \mathrm{~S}_{6} \\
69 \mathrm{~S}_{22}+19 \mathrm{~S}_{30}\end{array}$ \\
\hline
\end{tabular}


Table 2. Low frequency Raman bands of polycrystalline PDO observed at $10 \mathrm{~K}$ compared to values calculated by CRYSTALO9 program. For complete list of all phonons see Supplementary Material.v-very, s-strong, m-medium, w-weak, sh-shoulder, br-broad

\begin{tabular}{|c|c|c|}
\hline \multicolumn{2}{|c|}{$\begin{array}{l}\text { Partial list of calculated Raman phonons } \\
\qquad\left(\mathrm{cm}^{-1}\right)\end{array}$} & \multirow{2}{*}{$\begin{array}{c}\text { observed Raman bands } \\
\text { below } 550 \mathrm{~cm}^{-1} \text { at } 10 \mathrm{~K} \\
\left(\mathrm{~cm}^{-1}\right)\end{array}$} \\
\hline symmetry & value & \\
\hline$\overline{B_{g}}$ & 545 & \\
\hline $\mathrm{Ag}_{\mathrm{g}}$ & 541 & 535 \\
\hline $\mathrm{A}_{\mathrm{g}}$ & 466 & 445 \\
\hline $\mathrm{B}_{\mathrm{g}}$ & 453 & \\
\hline $\mathrm{B}_{\mathrm{g}}$ & 322 & 306 \\
\hline $\mathrm{A}_{\mathrm{g}}$ & 322 & $300 \mathrm{sh}$ \\
\hline $\mathrm{B}_{\mathrm{g}}$ & 290 & \\
\hline$A_{g}$ & 287 & 278 \\
\hline $\mathrm{A}_{\mathrm{g}}$ & 242 & 220 \\
\hline $\mathrm{A}_{\mathrm{g}}$ & 205 & 187 \\
\hline $\mathrm{B}_{\mathrm{g}}$ & 191 & \\
\hline $\mathrm{A}_{\mathrm{g}}$ & 155 & \\
\hline$B_{g}$ & 145 & \\
\hline $\mathrm{A}_{\mathrm{g}}$ & 135 & 124 \\
\hline $\mathrm{B}_{\mathrm{g}}$ & 126 & \\
\hline$B_{g}$ & 109 & \\
\hline$A_{g}$ & 108 & 102 \\
\hline$A_{g}$ & 88 & 80 \\
\hline $\mathrm{A}_{\mathrm{g}}$ & 73 & 75 \\
\hline$\overline{B_{g}}$ & 73 & \\
\hline $\mathrm{B}_{\mathrm{g}}$ & 64 & \\
\hline$A_{g}$ & 55 & 47 \\
\hline
\end{tabular}




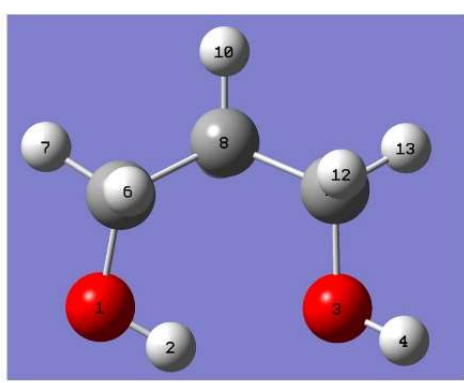

tGG'g

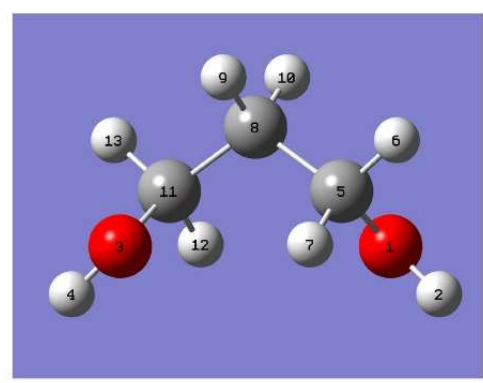

tGGt

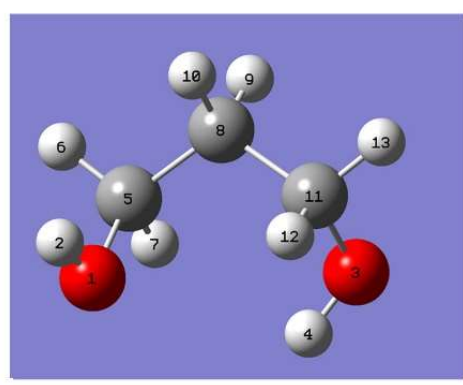

gGGg'

Figure 1. Labelling of atoms in 1,3-propanediol. Three most stable conformers are tGG'g, tGGt, and gGGg' (this work). 


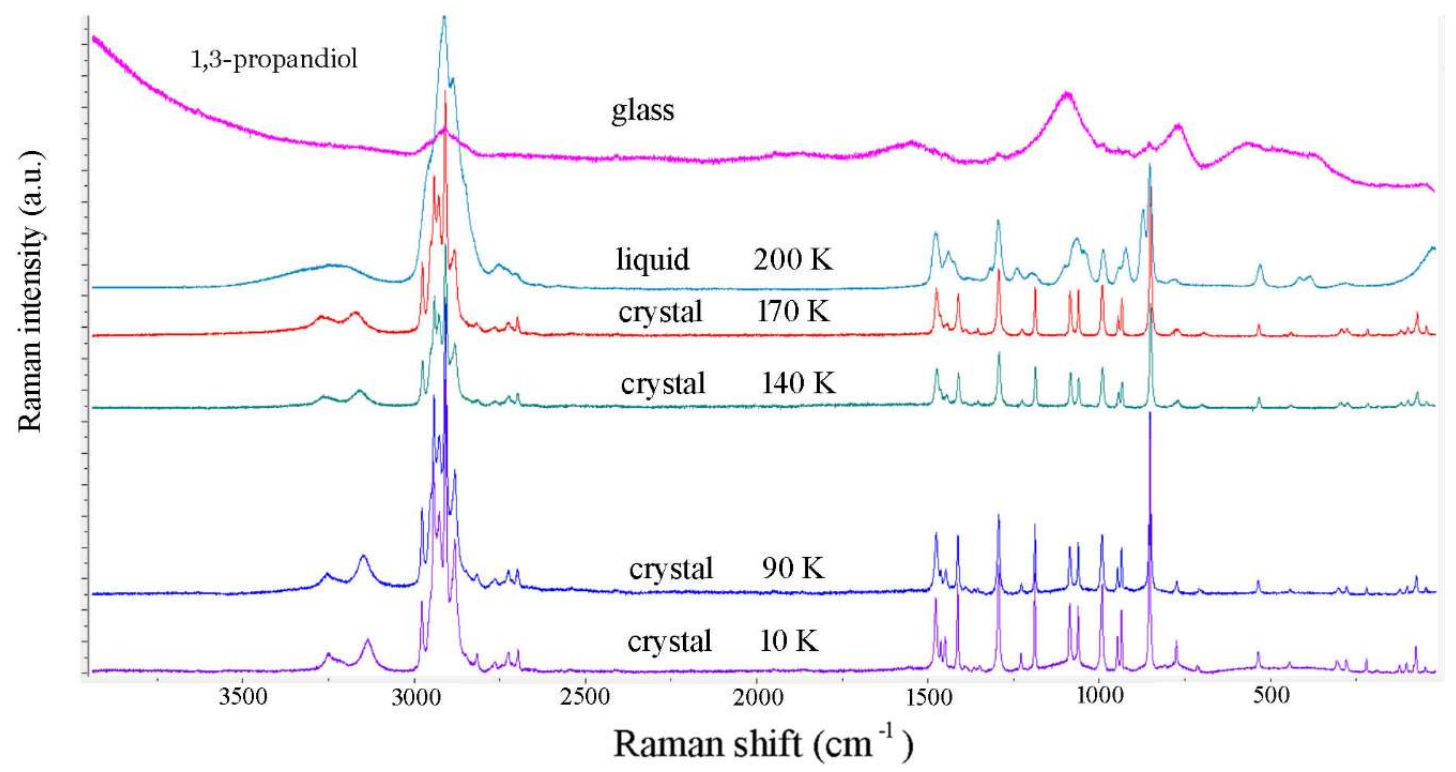

Figure 2. Comparison of Raman spectra of liquid (200 K) with Raman spectra of polycrystalline solid (170 K, $140 \mathrm{~K}, 90 \mathrm{~K}$ and $10 \mathrm{~K}$ ) and glass (10 K).

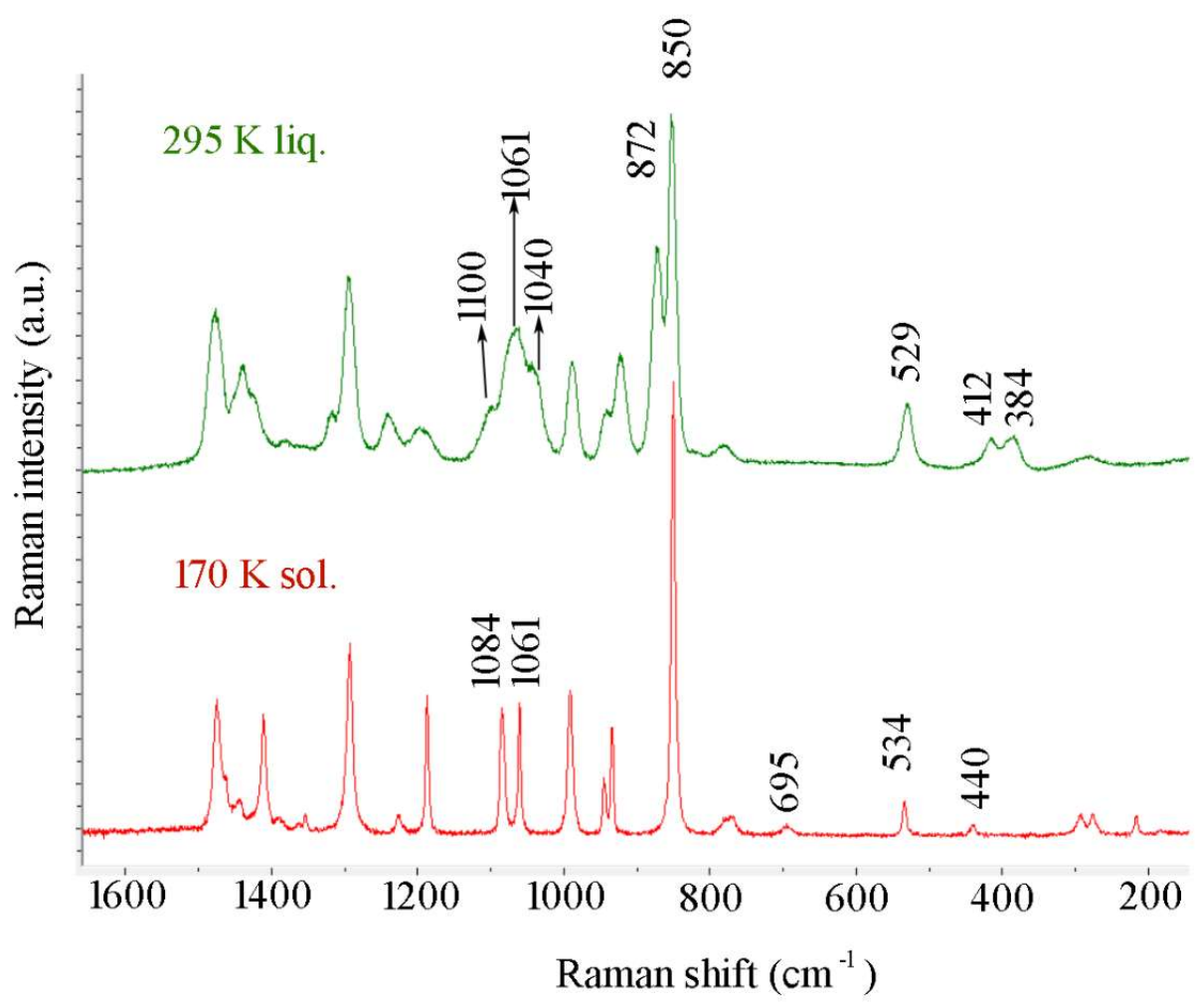

Figure 3. The disappearance of the 384,872 and $1040 \mathrm{~cm}^{-1}$ bands on crystallization of 1,3-propanediol. 


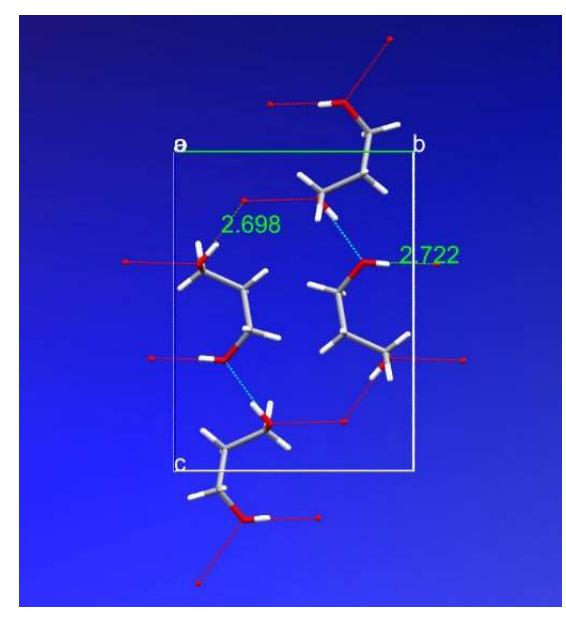

Figure 4. Crystal structure of 1,3-propanediol with two different O...O hydrogen bonds lengths in $\AA$ indicated. 

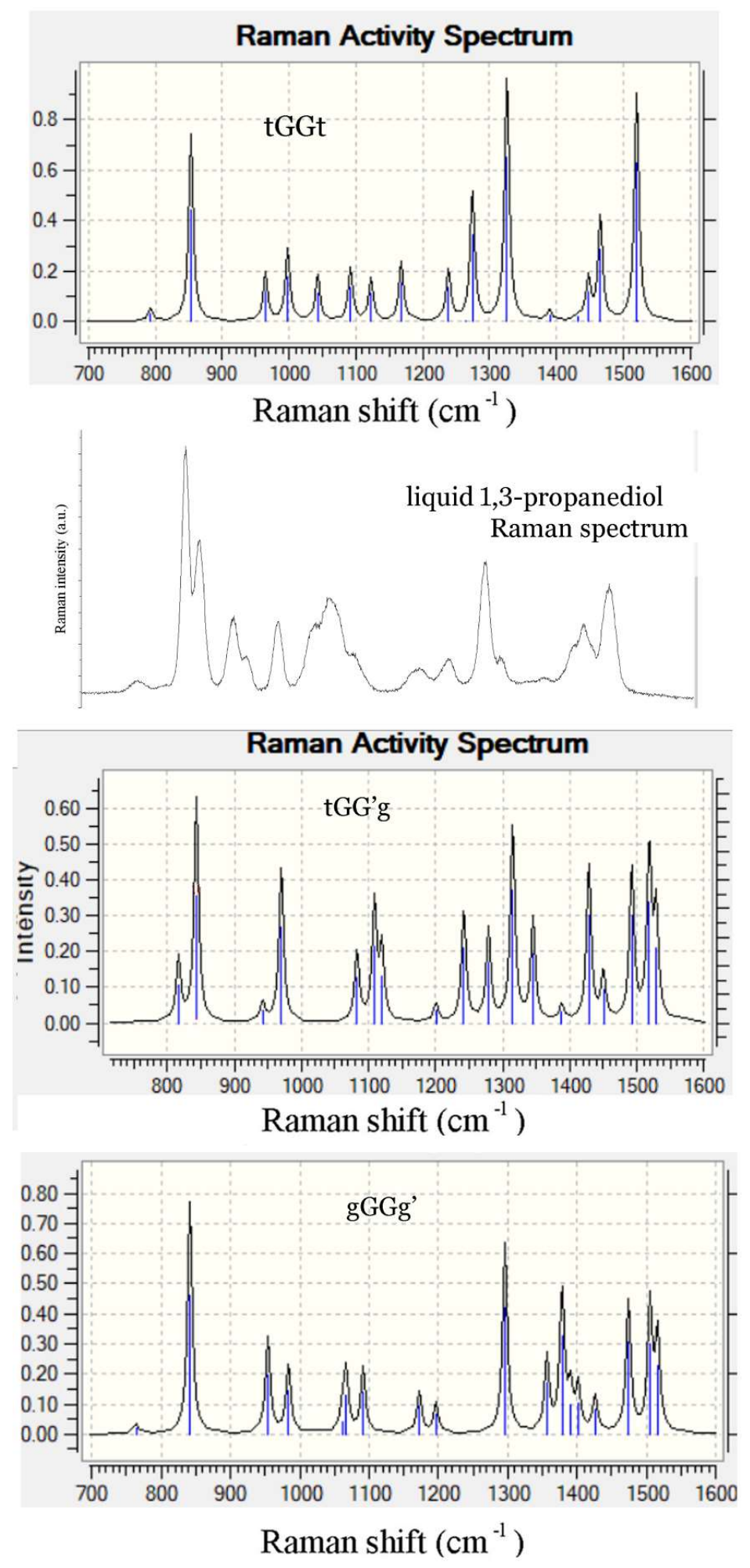

Figure 5. Calculated Raman spectra for three conformers of PDO are compared with the experimental spectrum $\left(700-1600 \mathrm{~cm}^{-1}\right)$. 
Supplementary table S1. Definition of internal coordinates in 1,3-propanediol.

Deformations of bond stretching coordinates

1. $\Delta \mathrm{l}_{1}=\Delta\left(\mathrm{O}_{1}-\mathrm{H}_{2}\right)$

2. $\Delta \mathrm{l}_{2}=\Delta\left(\mathrm{O}_{2}-\mathrm{H}_{4}\right)$

3. $\Delta \mathrm{r}_{2}=\Delta\left(\mathrm{C}_{5}-\mathrm{H}_{6}\right)$

4. $\Delta \mathrm{r}_{3}=\Delta\left(\mathrm{C}_{5}-\mathrm{H}_{7}\right)$

5. $\Delta \mathrm{r}_{5}=\Delta\left(\mathrm{C}_{11}-\mathrm{H}_{13}\right)$

6. $\Delta \mathrm{r}_{6}=\Delta\left(\mathrm{C}_{11}-\mathrm{H}_{12}\right)$

7. $\Delta \mathrm{r}_{7}=\Delta\left(\mathrm{C}_{8}-\mathrm{H}_{9}\right)$

8. $\Delta \mathrm{r}_{8}=\Delta\left(\mathrm{C}_{8}-\mathrm{H}_{10}\right)$

9. $\Delta \mathrm{L}_{1}=\Delta\left(\mathrm{C}_{5}-\mathrm{O}_{1}\right)$

10. $\Delta \mathrm{L}_{2}=\Delta\left(\mathrm{C}_{11}-\mathrm{O}_{3}\right)$

11. $\Delta \mathrm{R}_{1}=\Delta\left(\mathrm{C}_{5}-\mathrm{C}_{8}\right)$

12. $\Delta \mathrm{R}_{2}=\Delta\left(\mathrm{C}_{8}-\mathrm{C}_{11}\right)$

Deformations of bond angles coordinates:

13. $\Delta \omega=\Delta\left(\mathrm{C}_{5}-\mathrm{C}_{8}-\mathrm{C}_{11}\right)$

14. $\Delta \eta_{1}=\Delta\left(\mathrm{O}_{1}-\mathrm{C}_{5}-\mathrm{C}_{8}\right)$

15. $\Delta \eta_{2}=\Delta\left(\mathrm{O}_{3}-\mathrm{C}_{11}-\mathrm{C}_{8}\right)$

16. $\Delta \theta_{2}=\Delta\left(\mathrm{H}_{6}-\mathrm{C}_{5}-\mathrm{C}_{8}\right)$

17. $\Delta \theta_{3}=\Delta\left(\mathrm{H}_{7}-\mathrm{C}_{5}-\mathrm{C}_{8}\right)$

18. $\Delta \theta_{5}=\Delta\left(\mathrm{H}_{13}-\mathrm{C}_{11}-\mathrm{C}_{8}\right)$

19. $\Delta \theta_{6}=\Delta\left(\mathrm{H}_{12}-\mathrm{C}_{11}-\mathrm{C}_{8}\right)$

20. $\Delta \mathrm{a}_{2}=\Delta\left(\mathrm{H}_{6}-\mathrm{C}_{5}-\mathrm{O}_{1}\right)$

21. $\Delta \mathrm{a}_{3}=\Delta\left(\mathrm{H}_{7}-\mathrm{C}_{5}-\mathrm{O}_{1}\right)$

22. $\Delta \mathrm{a}_{5}=\Delta\left(\mathrm{H}_{13}-\mathrm{C}_{11}-\mathrm{O}_{3}\right)$

23. $\Delta \mathrm{a}_{6}=\Delta\left(\mathrm{H}_{12}-\mathrm{C}_{11}-\mathrm{O}_{3}\right)$

24. $\Delta \beta_{1}=\Delta\left(\mathrm{H}_{9}-\mathrm{C}_{8}-\mathrm{C}_{5}\right)$

25. $\Delta \beta_{2}=\Delta\left(\mathrm{H}_{10}-\mathrm{C}_{8}-\mathrm{C}_{11}\right)$

26. $\Delta \beta_{3}=\Delta\left(\mathrm{H}_{9}-\mathrm{C}_{8}-\mathrm{C}_{11}\right)$

27. $\Delta \beta_{4}=\Delta\left(\mathrm{H}_{10}-\mathrm{C}_{8}-\mathrm{C}_{5}\right)$

28. $\Delta \varepsilon_{1}=\Delta\left(\mathrm{H}_{2}-\mathrm{O}_{1}-\mathrm{C}_{5}\right)$

29. $\Delta \varepsilon_{2}=\Delta\left(\mathrm{H}_{4}-\mathrm{O}_{3}-\mathrm{C}_{11}\right)$

Torsional angle deformations

30. $\Delta \tau_{\mathrm{M}_{1}}=\Delta\left(\mathrm{H}_{7}-\mathrm{C}_{5}-\mathrm{C}_{8}-\mathrm{C}_{11}\right)+\Delta\left(\mathrm{H}_{6}-\mathrm{C}_{5}-\mathrm{C}_{8}-\mathrm{C}_{11}\right)+\Delta\left(\mathrm{O}_{1}-\mathrm{C}_{5}-\mathrm{C}_{8}-\mathrm{C}_{11}\right)$

31. $\Delta \mathrm{\tau}_{\mathrm{M} 2}=\Delta\left(\mathrm{H}_{13}-\mathrm{C}_{11}-\mathrm{C}_{8}-\mathrm{C}_{5}\right)+\Delta\left(\mathrm{H}_{12}-\mathrm{C}_{11}-\mathrm{C}_{8}-\mathrm{C}_{5}\right)+\Delta\left(\mathrm{O}_{3}-\mathrm{C}_{11}-\mathrm{C}_{8}-\mathrm{C}_{5}\right)$

32. $\Delta \mathrm{\tau OH}_{1}=\Delta\left(\mathrm{H}_{2}-\mathrm{O}_{1}-\mathrm{C}_{5}-\mathrm{C}_{8}\right)$

33. $\Delta \mathrm{\tau OH}_{2}=\Delta\left(\mathrm{H}_{4}-\mathrm{O}_{3}-\mathrm{C}_{11}-\mathrm{C}_{8}\right)$ 
Supplementary table S2. Definition of symmetrized coordinates for tTTt conformer of 1,3-propanediol. The same coordinates are used for other conformers as well.

\section{$11 \mathbf{A}_{1}$}

1. $\mathrm{S}_{1}=\Delta \mathrm{l}_{1}+\Delta \mathrm{l}_{2}$

2. $\mathrm{S}_{2}=\Delta \mathrm{r}_{2}+\Delta \mathrm{r}_{3}+\Delta \mathrm{r}_{5}+\Delta \mathrm{r}_{6}$

3. $\mathrm{S}_{3}=\Delta \mathrm{r}_{7}+\Delta \mathrm{r}_{8}$

4. $\mathrm{S}_{4}=\Delta \mathrm{L}_{1}+\Delta \mathrm{L}_{2}$

5. $\mathrm{S}_{5}=\Delta \mathrm{R}_{1}+\Delta \mathrm{R}_{2}$

6. $\mathrm{S}_{6}=\Delta \omega$

7. $\mathrm{S}_{7}=\Delta \mathrm{\eta}_{1}+\Delta \mathrm{\eta}_{2}$

8. $\mathrm{S}_{8}=\Delta \theta_{2}+\Delta \theta_{3}+\Delta \theta_{5}+\Delta \theta_{6}$

9. $\mathrm{S}_{9}=\Delta \mathrm{a}_{2}+\Delta \mathrm{a}_{3}+\Delta \mathrm{a}_{5}+\Delta \mathrm{a}_{6}$

10. $\mathrm{S}_{10}=\Delta \beta_{1}+\Delta \beta_{2}+\Delta \beta_{3}+\Delta \beta_{4}$

11. $\mathrm{S}_{11}=\Delta \varepsilon_{1}+\Delta \varepsilon_{2}$

\section{$6 \mathrm{~A}_{2}$}

12. $\mathrm{S}_{12}=\Delta \mathrm{r}_{2}-\Delta \mathrm{r}_{3}+\Delta \mathrm{r}_{5}-\Delta \mathrm{r} 6$

13. $\mathrm{S}_{13}=\theta_{2}-\Delta \theta_{3}+\Delta \theta_{5}-\Delta \theta_{6}$

14. $\mathrm{S}_{14}=\Delta \beta_{1}+\Delta \beta_{2}-\Delta \beta_{3}-\Delta \beta_{4}$

15. $\mathrm{S}_{15}=\Delta \alpha_{2}-\Delta \alpha_{3}+\Delta \alpha_{5}-\Delta \alpha_{6}$

16. $\mathrm{S}_{16}=\Delta \tau_{\mathrm{M} 1}+\Delta \tau_{\mathrm{M} 2}$

17. $\mathrm{S}_{17}=\Delta \mathrm{\tau OH}_{1}+\Delta \mathrm{\tau OH}_{2}$

\section{$9 \mathbf{B}_{1}$}

18. $\mathrm{S}_{18}=\Delta \mathrm{l}_{1}-\Delta \mathrm{l}_{2}$

19. $\mathrm{S}_{19}=\Delta \mathrm{r}_{2}+\Delta \mathrm{r}_{3}-\Delta \mathrm{r}_{5}-\Delta \mathrm{r}_{6}$

20. $\mathrm{S}_{20}=\Delta \mathrm{L}_{1}-\Delta \mathrm{L}_{2}$

21. $\mathrm{S}_{21}=\Delta \mathrm{R}_{1}-\Delta \mathrm{R}_{2}$

22. $\mathrm{S}_{22}=\Delta \eta_{1}-\Delta \eta_{2}$

23. $\mathrm{S}_{23}=\Delta \theta_{2}+\Delta \theta_{3}-\Delta \theta_{5}-\Delta \theta_{6}$

24. $\mathrm{S}_{24}=\Delta \mathrm{a}_{2}+\Delta \mathrm{a}_{3}-\Delta \mathrm{a}_{5}-\Delta \mathrm{a}_{6}$

25. $\mathrm{S}_{25}=\Delta \beta_{1}-\Delta \beta_{2}-\Delta \beta_{3}+\Delta \beta_{4}$

26. $\mathrm{S}_{26}=\Delta \varepsilon_{1}-\Delta \varepsilon_{2}$

\section{$7 \mathbf{B}_{2}$}

27. $\mathrm{S}_{27}=\Delta \mathrm{r}_{2}-\Delta \mathrm{r}_{3}+\Delta \mathrm{r}_{5}-\Delta \mathrm{r}_{6}$

28. $\mathrm{S}_{28}=\Delta \mathrm{r}_{7}-\Delta \mathrm{r} 8$

29. $\mathrm{S}_{29}=\Delta \theta_{2}-\Delta \theta_{3}-\Delta \theta_{5}+\Delta \theta_{6}$

30. $\mathrm{S}_{30}=\Delta \beta_{1}-\Delta \beta_{2}+\Delta \beta_{3}-\Delta \beta_{4}$

31. $\mathrm{S}_{31}=\Delta \alpha_{2}-\Delta \alpha_{3}-\Delta \alpha_{5}+\Delta \alpha_{6}$

32. $\mathrm{S}_{32}=\Delta \tau_{\mathrm{M} 1}-\Delta \tau_{\mathrm{M} 2}$

33. $\mathrm{S}_{33}=\Delta \mathrm{\tau OH}_{1}-\Delta \mathrm{\tau OH}_{2}$ 
Supplementary table S3. Unscaled normal modes of cis 1,3-propanediol with $\mathbf{C}_{\mathbf{2 v}}$ symmetry (tTTt) with potential energy distribution (PED) among symmetrized coordinates calculated by BALGA program are compared with the observed bands. Contributions greater than $10 \%$ are given. Observed bands typed in italic could not belong to this conformer.v-very, s-strong, mmedium, w-weak, sh-shoulder, br-broad

\begin{tabular}{|c|c|c|c|c|}
\hline $\begin{array}{l}\text { sym- } \\
\text { metry } \\
\mathbf{C}_{\mathbf{2 v}}\end{array}$ & $\begin{array}{l}\text { observed } \\
\text { Raman } \\
\text { liquid }\end{array}$ & $\begin{array}{l}\text { observed } \\
\text { infrared } \\
\text { liquid }\end{array}$ & calculated & PED (\%) \\
\hline $\mathbf{A}_{1}$ & $\begin{array}{l}3309 \mathrm{vbr} \\
2958 \mathrm{sh} \\
2913 \\
1476 \\
1440 \\
1426 \\
1293 \\
1097 \mathrm{sh} \\
1062 \\
986 \\
412 \\
384\end{array}$ & $\begin{array}{l}3335 \mathrm{vbr} \\
2883 \\
1474 \\
1433 \\
1377 \\
1231 \\
1063 \\
986\end{array}$ & $\begin{array}{l}3835 \\
3060 \\
2981 \\
1535 \\
1505 \\
1450 \\
1264 \\
1083 \\
1009 \\
411 \\
197\end{array}$ & $\begin{array}{l}100 \mathrm{~S}_{1} \\
99 \mathrm{~S}_{3} \\
99 \mathrm{~S}_{2} \\
54 \mathrm{~S}_{9}+33 \mathrm{~S}_{8}+10 \mathrm{~S}_{10} \\
83 \mathrm{~S}_{10} \\
42 \mathrm{~S}_{8}+39 \mathrm{~S}_{9} \\
62 \mathrm{~S}_{11}+17 \mathrm{~S}_{8} \\
91 \mathrm{~S}_{4} \\
54 \mathrm{~S}_{5}+24 \mathrm{~S}_{11}+11 \mathrm{~S}_{7} \\
31 \mathrm{~S}_{5}+28 \mathrm{~S}_{7}+28 \mathrm{~S}_{6}+12 \mathrm{~S}_{4} \\
51 \mathrm{~S}_{6}+45 \mathrm{~S}_{7}\end{array}$ \\
\hline$\overline{\mathbf{A}_{2}}$ & $\begin{array}{c}2958 \mathrm{sh} \\
1316 \mathrm{sh} \\
1238 \\
871 \\
850 \\
278 \\
---\end{array}$ & inactive & $\begin{array}{c}3004 \\
1312 \\
1229 \\
896 \\
\\
273 \\
106\end{array}$ & $\begin{array}{l}100 \mathrm{~S}_{12} \\
53 \mathrm{~S}_{14}+36 \mathrm{~S}_{13}+10 \mathrm{~S}_{15} \\
78 \mathrm{~S}_{15}+23 \mathrm{~S}_{14} \\
65 \mathrm{~S}_{13}+24 \mathrm{~S}_{14}+11 \mathrm{~S}_{15} \\
\\
99 \mathrm{~S}_{17} \\
98 \mathrm{~S}_{16}\end{array}$ \\
\hline$\overline{\mathbf{B}_{1}}$ & $\begin{array}{l}3309 \mathrm{vbr} \\
1476 \\
1440 \\
1318 \\
1193 \\
1039 \mathrm{sh} \\
941 \\
920 \\
529\end{array}$ & $\begin{array}{l}3335 \mathrm{vbr} \\
1474 \\
1422 \\
1355 \\
1184 \\
1038 \\
940 \\
921 \\
528\end{array}$ & $\begin{array}{l}3835 \\
2972 \\
1525 \\
1461 \\
1328 \\
1200 \\
1054 \\
1015 \\
461\end{array}$ & $\begin{array}{l}100 \mathrm{~S}_{18} \\
97 \mathrm{~S}_{19} \\
63 \mathrm{~S}_{24}+32 \mathrm{~S}_{23} \\
45 \mathrm{~S}_{23}+25 \mathrm{~S}_{24}+13 \mathrm{~S}_{25} \\
66 \mathrm{~S}_{25}+20 \mathrm{~S}_{26} \\
60 \mathrm{~S}_{26}+17 \mathrm{~S}_{23}+10 \mathrm{~S}_{24} \\
44 \mathrm{~S}_{21}+38 \mathrm{~S}_{20} \\
61 \mathrm{~S}_{20}+36 \mathrm{~S}_{22} \\
89 \mathrm{~S}_{22}\end{array}$ \\
\hline $\mathbf{B}_{2}$ & $\begin{array}{r}2958 \\
2887 \\
1293 \\
1196 \\
782 \\
280\end{array}$ & $\begin{array}{c}2945 \\
2883 \\
1292 \\
1184 \\
782\end{array}$ & $\begin{array}{c}3109 \\
3011 \\
1308 \\
1171 \\
784 \\
274 \\
114\end{array}$ & $\begin{aligned} & 97 \mathrm{~S}_{28} \\
& 100 \mathrm{~S}_{27} \\
& 50 \mathrm{~S}_{29}+37 \mathrm{~S}_{31}+13 \mathrm{~S}_{30} \\
& 59 \mathrm{~S}_{31}+25 \mathrm{~S}_{30}+17 \mathrm{~S}_{29} \\
& 64 \mathrm{~S}_{30}+31 \mathrm{~S}_{29} \\
& 99 \mathrm{~S}_{17} \\
& 100 \mathrm{~S}_{32}\end{aligned}$ \\
\hline
\end{tabular}


Supplementary table S4. Unscaled normal modes of gGG'g 1,3-propanediol are compared with the observed bands. Potential energy distribution (PED) among symmetrized coordinates is calculated by BALGA program. Contributions greater than $10 \%$ are given.v-very, s-strong, mmedium, w-weak, sh-shoulder, br-broad

\begin{tabular}{|c|c|c|c|c|c|}
\hline \multirow[t]{2}{*}{$\begin{array}{l}\text { sym- } \\
\text { metry } \\
\mathbf{C}_{\mathbf{1}}\end{array}$} & $\begin{array}{l}\text { observed } \\
\text { Raman } \\
\text { liquid }\end{array}$ & $\begin{array}{l}\text { observed } \\
\text { Raman } \\
\text { cryst 10 K }\end{array}$ & $\begin{array}{l}\text { observed } \\
\text { infrared } \\
\text { liquid }\end{array}$ & $\begin{array}{l}\text { Calculated } \\
\text { gGG'g }\end{array}$ & $\begin{array}{l}\text { PED (\%) } \\
\text { gGG'g }\end{array}$ \\
\hline & $\begin{array}{l}3309 \mathrm{w}, \mathrm{vbr} \\
\\
2958 \mathrm{~s}, \mathrm{sh} \\
2913 \mathrm{vs} \\
2887 \mathrm{vs} \\
\\
1476 \mathrm{~ms} \\
1440 \mathrm{~m} \\
1426 \mathrm{~m}, \mathrm{sh} \\
\\
1316 \mathrm{~m}, \mathrm{sh} \\
1294 \mathrm{~ms} \\
1238 \mathrm{~m} \\
1193 \mathrm{~m} \\
1097 \mathrm{~m}, \mathrm{sh} \\
1062 \mathrm{~ms} \\
1040 \mathrm{~m}, \mathrm{sh} \\
986 \mathrm{~m} \\
941 \mathrm{~m} \\
920 \mathrm{~m} \\
872 \mathrm{~s} \\
850 \mathrm{~s} \\
815 \mathrm{w} \\
782 \mathrm{w} \\
529 \mathrm{mw} \\
412 \mathrm{w} \\
384 \mathrm{w} \\
278 \mathrm{vw}\end{array}$ & $\begin{array}{l}3250 \mathrm{~m} \\
3236 \mathrm{mw} \\
3135 \mathrm{~m}, \mathrm{br} \\
2978 \mathrm{~ms} \\
2954 \mathrm{~s}, \mathrm{sh} \\
2943 \mathrm{vs} \\
2927 \mathrm{~s} \\
2908 \mathrm{vs} \\
2889 \mathrm{~m}, \mathrm{sh} \\
2881 \mathrm{~s} \\
\\
1477 \mathrm{~s} \\
1463 \mathrm{~m} \\
1450 \mathrm{~m} \\
\\
1413 \mathrm{~s} \\
1391 \mathrm{w} \\
1366 \mathrm{w} \\
1348 \mathrm{w} \\
1294 \mathrm{~s} \\
1228 \mathrm{mw} \\
1189 \mathrm{~s}\end{array}$ & $\begin{array}{l}2945 \mathrm{~s} \\
2883 \mathrm{~s} \\
1474 \mathrm{~ms} \\
1433 \mathrm{~s} \\
\\
1377 \mathrm{~ms} \\
1355 \mathrm{~ms} \\
1292 \mathrm{~m} \\
1231 \mathrm{~m} \\
1184 \mathrm{~m} \\
1063 \mathrm{vs} \\
1038 \mathrm{~s} \\
986 \mathrm{~s} \\
940 \mathrm{~m} \\
921 \mathrm{~m} \\
869 \mathrm{w} \\
847 \mathrm{w} \\
782 \mathrm{~m} \\
666 \mathrm{~m}, \mathrm{vbr} \\
528 \mathrm{~m}\end{array}$ & $\begin{array}{l}3829 \\
3825 \\
\\
\\
3099 \\
3086 \\
3063 \\
3039 \\
3017 \\
3015 \\
\\
1515 \\
1502 \\
1468 \\
1422 \\
1400 \\
1390 \\
1376 \\
1364 \\
1281 \\
1244 \\
1160 \\
\\
1094 \\
1075 \\
1052 \\
\\
949 \\
927 \\
886 \\
\\
\\
\\
\\
181 \\
515 \\
\\
387 \\
368 \\
323 \\
\\
\\
\\
125 \\
107\end{array}$ & $\begin{array}{l}67 \mathrm{~S}_{18}+33 \mathrm{~S}_{1} \\
67 \mathrm{~S}_{1}+33 \mathrm{~S}_{18} \\
48 \mathrm{~S}_{19}+28 \mathrm{~S}_{12}+20 \mathrm{~S}_{27} \\
54 \mathrm{~S}_{12}+35 \mathrm{~S}_{19} \\
84 \mathrm{~S}_{28} \\
47 \mathrm{~S}_{2}+45 \mathrm{~S}_{27} \\
48 \mathrm{~S}_{3}+28 \mathrm{~S}_{27} \\
43 \mathrm{~S}_{3}+27 \mathrm{~S}_{2}+14 \mathrm{~S}_{27} \\
44 \mathrm{~S}_{9}+37 \mathrm{~S}_{8} \\
55 \mathrm{~S}_{24}+27 \mathrm{~S}_{23} \\
90 \mathrm{~S}_{10} \\
42 \mathrm{~S}_{8}+40 \mathrm{~S}_{9} \\
40 \mathrm{~S}_{23}+19 \mathrm{~S}_{24}+15 \mathrm{~S}_{26} \\
41 \mathrm{~S}_{25}+18 \mathrm{~S}_{13}+18 \mathrm{~S}_{15} \\
26 \mathrm{~S}_{31}+22 \mathrm{~S}_{23}+20 \mathrm{~S}_{26} \\
31 \mathrm{~S}_{11}+18 \mathrm{~S}_{15}+17 \mathrm{~S}_{25} \\
32 \mathrm{~S}_{14}+24 \mathrm{~S}_{29} \\
30 \mathrm{~S}_{29}+22 \mathrm{~S}_{14}+15 \mathrm{~S}_{26} \\
30 \mathrm{~S}_{15}+26 \mathrm{~S}_{11}+17 \mathrm{~S}_{14} \\
28 \mathrm{~S}_{4}+16 \mathrm{~S}_{20}+12 \mathrm{~S}_{21} \\
36 \mathrm{~S}_{21}+26 \mathrm{~S}_{20} \\
23 \mathrm{~S}_{31}+19 \mathrm{~S}_{30}+17 \mathrm{~S}_{26} \\
\\
50 \mathrm{~S}_{20}+22 \mathrm{~S}_{21} \\
25 \mathrm{~S}_{30}+16 \mathrm{~S}_{7}+15 \mathrm{~S}_{29}+15 \mathrm{~S}_{5} \\
64 \mathrm{~S}_{13}+17 \mathrm{~S}_{15} \\
63 \mathrm{~S}_{5}+16 \mathrm{~S}_{30}+15 \mathrm{~S}_{4} \\
60 \mathrm{~S}_{33}+36 \mathrm{~S}_{32} \\
42 \mathrm{~S}_{7}+24 \mathrm{~S}_{30}+16 \mathrm{~S}_{6} \\
87 \mathrm{~S}_{17} \\
75 \mathrm{~S}_{22} \\
32 \mathrm{~S}_{6}+31 \mathrm{~S}_{32} \\
\\
31 \mathrm{~S}_{33}+21 \mathrm{~S}_{6}+20 \mathrm{~S}_{32} \\
82 \mathrm{~S}_{16}+10 \mathrm{~S}_{32}\end{array}$ \\
\hline
\end{tabular}




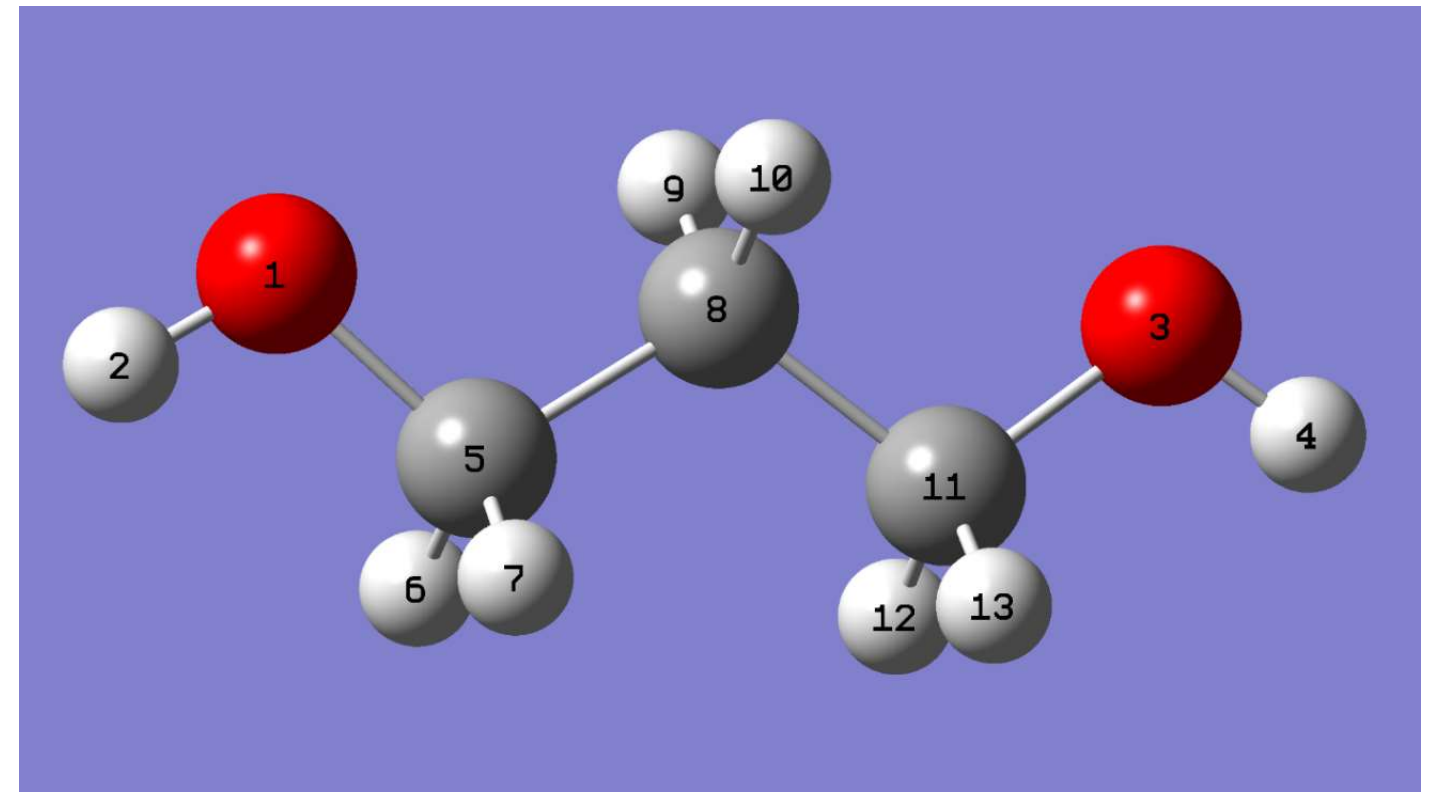

Supplementary figure S1. Labeling of atoms in 1,3-propanediol, tTTt conformer. The list of internal coordinates is given in Supplementary table S1. 

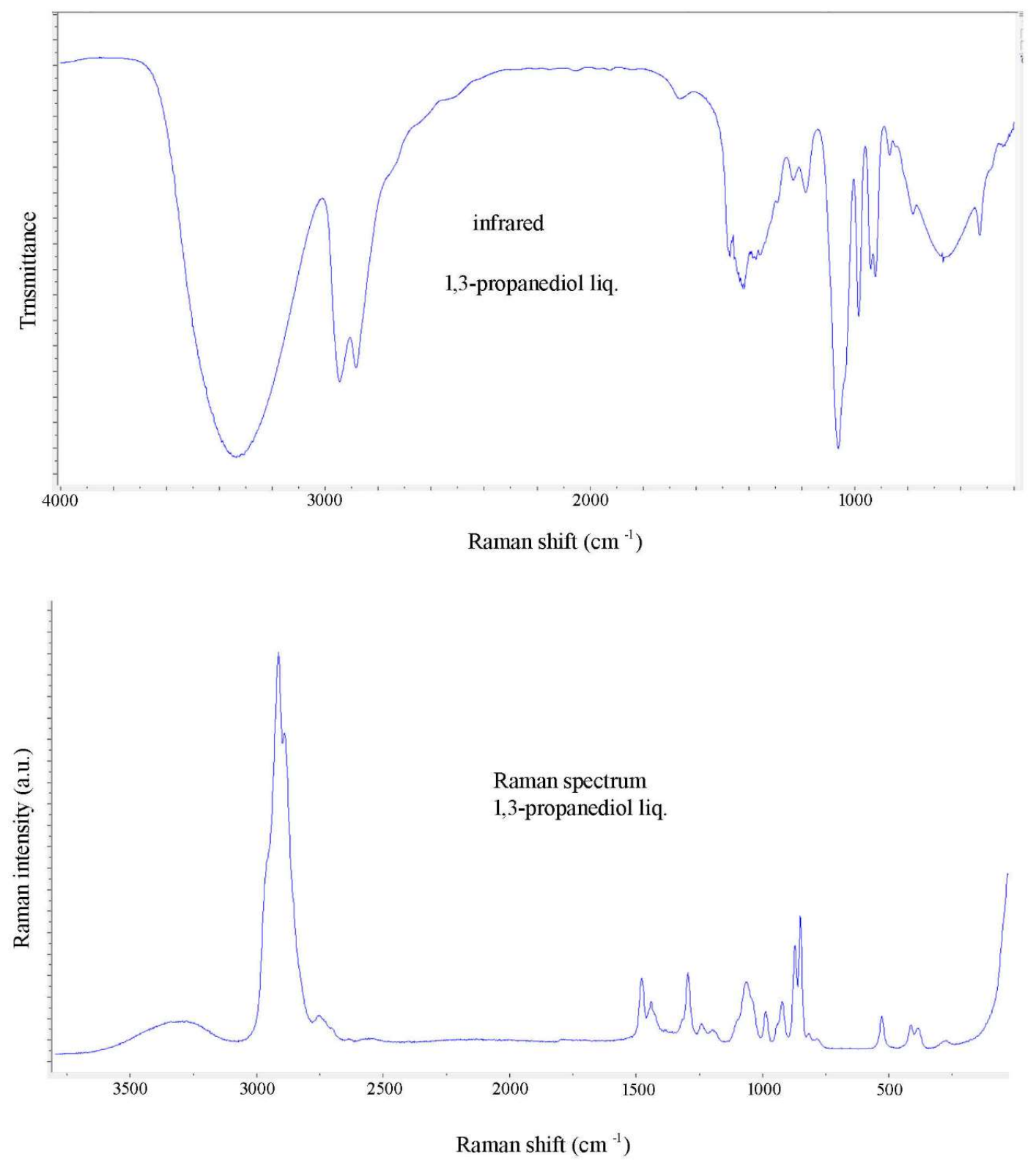

Supplementary figure S2. Comparison of infrared and Raman spectra of liquid 1,3propanediol. 


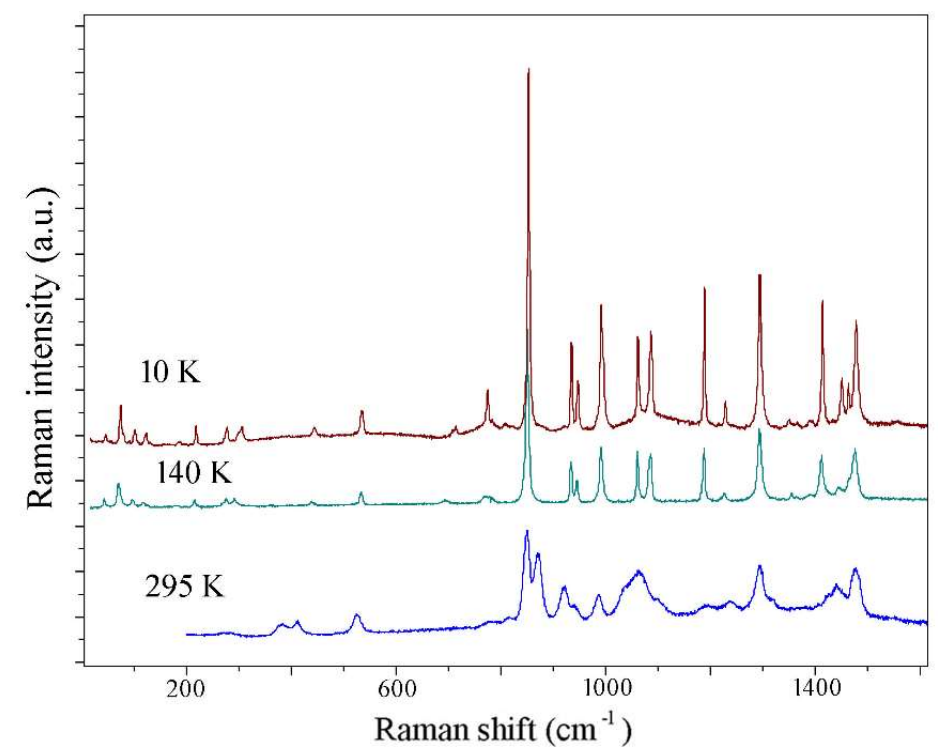

Supplementary figure S3. Low temperature Raman spectra of 1,3-propanediol (10$\left.1600 \mathrm{~cm}^{-1}\right)$.

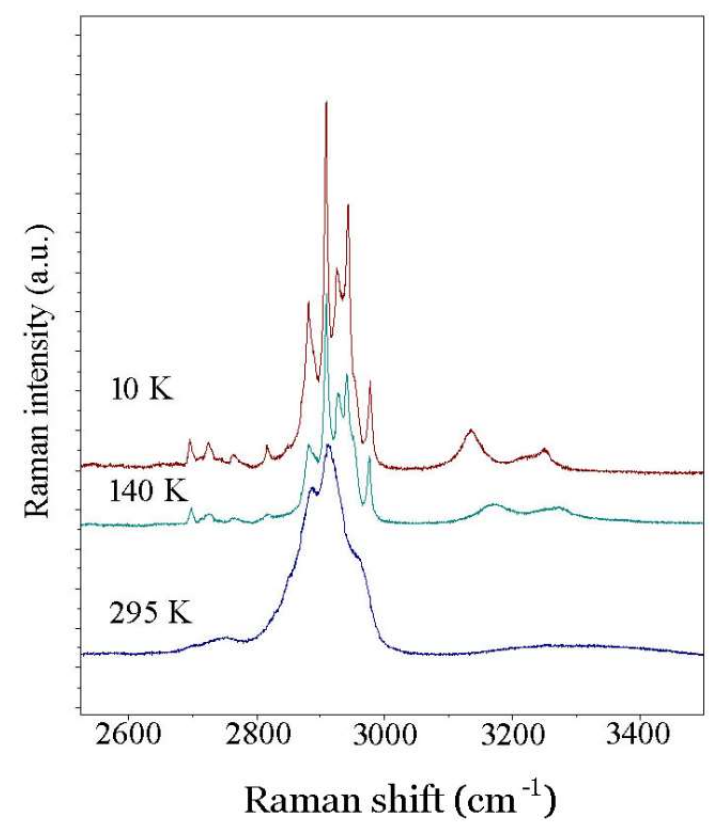

Supplementary figure S4. Low temperature Raman spectra of 1,3-propanediol (2800 $-3500 \mathrm{~cm}^{-1}$ ). 


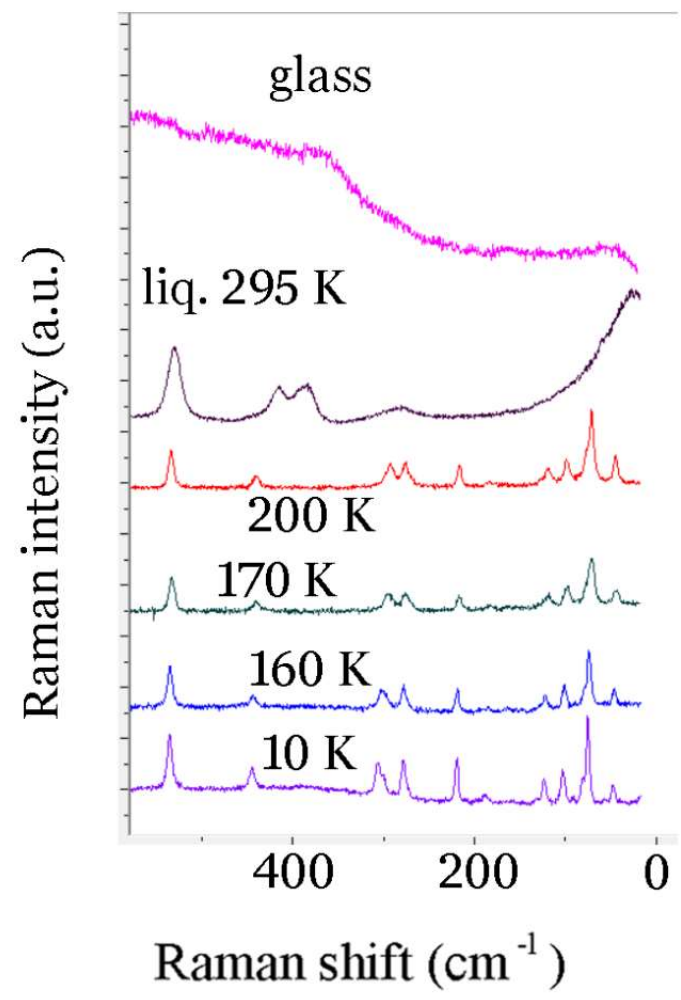

Supplementary figure $\mathrm{S}_{5}$. Comparison of low frequency Raman spectra of liquid (295 K) with Raman spectra of polycrystalline solid 1,3-propanediol (200 K, $170 \mathrm{~K}, 160 \mathrm{~K}$, $10 \mathrm{~K})$. 